\title{
The Influence of cassava peel meal on egg quality and reproductive characteristics of dominant Black Pullets in Makurdi, Benue State, Nigeria
}

\author{
Ezihe, C. $0.1^{*}$ and Uchendu, C. I. ${ }^{2}$ \\ ${ }^{1}$ Department of Veterinary Physiology, Pharmacology and Biochemistry, University of Agriculture, Makurdi, Nigeria. \\ ${ }^{2}$ Department of Veterinary Physiology and Pharmacology, University of Nigeria Nsukka, Nigeria. \\ ${ }^{*}$ Corresponding author. Email: chrisezihe@yahoo.com
}

Copyright @ 2017 Ezihe and Uchendu. This article remains permanently open access under the terms of the Creative Commons Attribution License 4.0, which permits unrestricted use, distribution, and reproduction in any medium, provided the original work is properly cited.

Received 26th April, 2017; Accepted 31st May, 2017

\begin{abstract}
This work was designed to determine the effect of cassava peel meal on egg quality and reproductive characteristics of Dominant Black pullets. One hundred and twenty (120) dominant black layer breed, comprising 108 pullets at the point of lay and 12 cocks were used in this study. The birds were assigned to three dietary groups containing cassava peel meal at $0 \%$ (T1), 10\% (T2) and 20\% (T3), in a completely randomized design (CRD). The birds were given feed and water ad libitum. Ages of birds at first egg as well as weight of first egg were recorded. Data were collected on egg weight, egg length, egg width, shell weight, shell thickness, egg shape index and albumen height. Data were also collected on infertility and hatchability. Data were subjected to analysis of variance, and significant means were separated using Duncan's multiple range test. The results of this study revealed that inclusion of cassava peel meal in the diets of pullets did not significantly $(P>0.05)$ affect the mean egg length, egg width, egg shape index, egg weight, shell weight, shell thickness and albumen height of eggs from the three dietary groups. However, a negative trend in egg weight could be observed as the level of inclusion of cassava peel meal increased in the diets. This suggests that increase in the inclusion level of cassava peel meal could result in a decline in egg weight. Significant differences $(P<0.05)$ were observed in age at first egg $(A F E)$, weight of first egg (WFE), hatchability and infertility of eggs of pullets on the three dietary groups. Pullets on the control diet had the lowest AFE, $138 \pm 0.80$ days, which suggests that inclusion of cassava peel meal in the diet of pullets may have prolonged AFE.
\end{abstract}

Keywords: Diets, hatchability, infertility, layers, pullets, egg quality.

\section{INTRODUCTION}

Poultry production is one of the veritable sources of protein in the form of meat and egg to the world. Among the numerous species of poultry is the domestic chicken. Pullets are chickens, which are characteristically kept majorly for their proficiency in egg production and subsequently for meat as old layers. Several breeds of layer chickens, including dominant black pullets, have been developed in different regions of the world, specifically for egg production. For the egg industry worldwide, the production of eggs which are of good egg shell quality and good internal quality is critical to the economic viability of the industry (Ahmadi and Rahimi, 2011).
Poultry production in Nigeria is presently facing many problems triggered by rising cost of conventional feed ingredients. This is worsened largely by competition from the increasing human population in Nigeria. Consequently, there is competition between man and farm livestock on the available conventional feed ingredients, particularly maize. For example, maize being a multi-purpose farm produce in Nigeria serves not only as staple food for a large proportion of Nigerians but also as a raw material for the beer brewing industries among others (Obiakonu and Udedibie, 2007). Thus, the option has been to source locally available plant materials, which are not directly consumed by humans for mono- 
gastric animal production (Esonu et al., 2004).

One of the potentially available crop wastes is cassava peels, which is a waste from cassava root (Manihot utilisima) obtained by removing the outer cover of cassava root with sharp knife. Cassava peel could serve as a cheap and alternative source of energy to poultry species, and in ruminant feeding systems, serving either as the main basal diet or as a supplement (Anaeto et al., 2013). Although cassava peel has lower crude protein and energy than maize, the greatest limitation in the use of cassava peel as a substitute for maize is that of its hydrocyanic acid (HCN) content which is harmful to the monogastric animals (Salami and Odunsi, 2003). In order to increase acceptability and subsequent utilization of cassava peel, the HCN content of fresh cassava peels has to be reduced greatly (Salami and Odunsi, 2003). The inclusion of cassava peel meal up to $30 \%$ in the diets of growing pigs has been performedwithout resultant deleterious effect (Irekhore et al., 2006).

With the ever growing cost of poultry feed, there is need to evaluate the potential of cassava peel meal as an alternative feed ingredient in laying hen diets. The objective of this study therefore, was to determine the effect of cassava peel meal on egg quality and reproductive characteristics of dominant black pullets.

\section{MATERIALS AND METHODS}

\section{Location of study}

This study was carried out in Makurdi, Benue state. Makurdi is located in the Guinea Savannah belt of Nigeria on latitude $74^{\circ} 3^{\prime} \mathrm{N}$ and longitude $8^{\circ} 3^{\prime} \mathrm{E}$. The area is warm with a minimum temperature range of $17.3^{\circ} \mathrm{C}$ to $24.5^{\circ} \mathrm{C}$ and a maximum temperature range of $29.8^{\circ} \mathrm{C}$ to $35.6^{\circ} \mathrm{C}$ (TAC, 2002). The area is characterized by two seasons a period of dry season from October to March, and a period of rainy season from April to September. Annual rainfall in Makurdi ranges from 973 to $1324 \mathrm{~mm}$.

\section{Preparation of experimental diet}

Fresh cassava peels were collected from garri processing centers in Agan community of Benue state. The cassava peels used in this study were prepared by thoroughly washing the peels to remove sand particles and debris. The peels were soaked in a closed metal drum containing water, for five days. The peels were then drained with basket and subsequently sun-dried for 3 to 5 days. The peels were hammer-milled to give cassava peel meal. The experimental diets were thereafter prepared to contain $0 \%(\mathrm{~T} 1), 10 \%$ (T2) and $20 \%$ (T3) cassava peel meal, with T1 serving as the control diet (Table 1). Other feed ingredients added were fish meal, maize bran, maize, bone meal, limestone, Methionine, vitamin premix (layer) and salt.

\section{Experimental birds and management}

One hundred and twenty (120) Dominant Black layer breed, comprising 108 pullets at the point of lay and 12 cocks were used in this study. The pullets were randomly assigned to three experimental layer diets (treatments) with each dietary group containing thirty-six (36) pullets, in a completely randomized design (CRD). The cocks were also assigned to the three dietary groups with each group containing four (4) cocks. Feed and water were given to the birds ad libitum. The pullets were housed in a deep litter system. Standard vaccination programme for layer chicken management was carried out at appropriate periods. Other management practices such as deworming, debeaking and administration of antibiotics and vitamins were also carried out at appropriate periods.

\section{Data collection}

As soon as the pullets started laying, their ages at first egg (AFE) were recorded. The weight of the first eggs (WFE) dropped were also measured and recorded. Egg weight was measured using a sensitive electronic weighing balance (Mettler SB 12001). The egg length and egg width were measured with the venier calipers. Eggshell thickness (in $\mathrm{mm}$ ) was measured using the micrometer screw gauge. The average of two egg shell measurements per egg was taken as the eggshell thickness. Eggshell weight was also recorded as the weight after breaking the egg and the content poured onto a separate plate. Albumen height was measured with vernier calipers. Egg shape index was calculated as defined in the following formula.

Egg shape index (\%) $=\frac{\text { egg width }}{\text { egg length }} \times 100$

Forty (40) eggs from each treatment group were set on incubator in order to determine the infertility and hatchability of eggs. Infertility and hatchability were defined by the following expressions.

Infertility $=\frac{T e-F e}{T e} \times 100$

Where: $\mathrm{Te}=$ total number of eggs incubated and $\mathrm{Fe}=$ total number of fertile eggs

Hatchability $=\frac{H e}{V e} \times 100$

Where: $\mathrm{He}=$ total number of hatched eggs and $\mathrm{Ve}=$ total number of viable eggs after candling.

\section{Statistical analysis}

Data were subjected to Analysis of Variance (ANOVA) using Statistical Package for the Social Sciences (SPSS, 
Table 1.Percentage Composition of Layer Diets.

\begin{tabular}{lccc}
\hline \multirow{2}{*}{ Feedstuff } & \multicolumn{3}{c}{ Diets } \\
\cline { 2 - 4 } & T1 (0\%) & T2 (10\%) & T3 (20\%) \\
\hline Cassava Peel Meal & 0.00 & 10.00 & 20.00 \\
Fish Meal & 2.00 & 2.00 & 3.00 \\
Soyabean Meal & 30.00 & 30.00 & 25.00 \\
Maize Bran & 9.60 & - & - \\
Maize & 48.00 & 47.60 & 43.70 \\
Bone Meal & 3.50 & 3.50 & 3.50 \\
Limestone & 6.00 & 6.00 & 4.50 \\
Methionine & 0.30 & 0.30 & 0.30 \\
Premix (Layers) & 0.30 & 0.30 & 0.25 \\
Salt & 0.30 & 0.30 & 0.25 \\
Total & $\mathbf{1 0 0 . 0 0}$ & $\mathbf{1 0 0 . 0 0}$ & $\mathbf{1 0 0 . 0 0}$ \\
Calculated Analysis & & & \\
Crude Protein \% & & & \\
Energy Kcal/kg ME & 17.51 & 18.20 & 17.40 \\
Calcium \% & 2733 & 2705 & 2630 \\
Phosphorus \% & 3.50 & 3.67 & 2.93 \\
Methionine & 0.845 & 0.840 & 0.851 \\
Lysine \% & 0.574 & 0.592 & 0.541 \\
\hline
\end{tabular}

Table 2. The Influence of Cassava Peel Meal on Egg Characteristics of Dominant Black Pullets.

\begin{tabular}{|c|c|c|c|c|}
\hline \multirow{2}{*}{ Egg Characteristics } & \multicolumn{3}{|c|}{ Diets (Mean \pm SEM) } & \multirow{2}{*}{ LS } \\
\hline & T1 (0\%) & T2 (10\%) & T3 (20\%) & \\
\hline Egg length $(\mathrm{cm})$ & $5.88 \pm 0.03$ & $5.93 \pm 0.04$ & $5.75 \pm 0.03$ & NS \\
\hline Egg width $(\mathrm{cm})$ & $4.46 \pm 0.03$ & $4.37 \pm 0.03$ & $4.34 \pm 0.02$ & NS \\
\hline Egg Shape Index & $1.31 \pm 0.02$ & $1.33 \pm 0.02$ & $1.33 \pm 0.001$ & NS \\
\hline Egg Weight (g) & $61.74 \pm 0.99$ & $60.95 \pm 1.02$ & $59.08 \pm 0.49$ & NS \\
\hline Shell Weight (g) & $5.42 \pm 0.11$ & $5.38 \pm 0.13$ & $5.08 \pm 0.06$ & NS \\
\hline Shell Thickness (mm) & $0.38 \pm 0.01$ & $0.37 \pm 0.01$ & $0.36 \pm 0.01$ & NS \\
\hline Albumen Height $(\mathrm{cm})$ & $0.66 \pm 0.02$ & $0.76 \pm 0.03$ & $0.63 \pm 0.02$ & NS \\
\hline
\end{tabular}

$\mathrm{SEM}=$ Standard error of the mean; $L S=$ Level of significance; $N S=$ non-significant $(P>0.05)$.

2011) version 20.0, and significant means were separated using Duncan's multiple range test.

\section{RESULTS AND DISCUSSIONS}

The results of influence of cassava peel meal on egg characteristics of Dominant Black layers are shown in Table 2, while the influence of cassava peel meal on reproductive characteristics of Dominant Black pullets were shown in Table 3. The results of this study showed that there were no significant differences $(P>0.05)$ in the mean egg length, egg width, egg shape index, egg weight, shell weight, shell thickness and albumen height of eggs from the three dietary groups. However, a negative trend in egg weight could be observed as the level of inclusion of cassava peel meal increased in the diets. This suggests that increase in the inclusion level of cassava peel meal could result in a decline in egg weight. Again, egg shell weight decreased as the inclusion level of cassava peel meal in the diets increased. In addition, egg width also increased as the inclusion level of cassava peel meal in the diets increased. There was no significant differences in external egg characteristics of pullets fed diets containing graded levels of cassava peel meal had been reported. Olowofeso and Omisami (2008) observed that egg laying chickens fed varying levels of sun-dried cassava peel treated with yeast did not affect egg weight, egg width, egg length, egg shell weight, egg shell thickness, shape index and albumen weight. Mean 
Table 3. The influence of Cassava Peel Meal on Reproductive Characteristics of Dominant Black Pullets.

\begin{tabular}{lccc}
\hline \multirow{2}{*}{ Parameters } & \multicolumn{3}{c}{ Diets (Mean \pm SEM) } \\
\cline { 2 - 4 } & T1 (0\%) & T2 (10\%) & T3 (20\%) \\
\hline Number of Egg Set & 40 & 40 & 40 \\
Dead in Shell \% & $45.50 \pm 0.08^{\mathrm{c}}$ & $60.00 \pm 0.79^{\mathrm{b}}$ & $62.50 \pm 0.08^{\mathrm{a}}$ \\
Infertility \% & $50.00 \pm 0.79^{\mathrm{a}}$ & $40.00 \pm 0.71^{\mathrm{b}}$ & $32.53 \pm 0.17^{\mathrm{c}}$ \\
Hatchability \% & $5.26 \pm 0.01^{\mathrm{b}}$ & $0.00 \pm 0.00^{\mathrm{c}}$ & $8.00 \pm 0.04^{\mathrm{a}}$ \\
Age at First Egg (AFG) (days) & $138 \pm 0.80^{\mathrm{c}}$ & $145 \pm 0.44^{\mathrm{a}}$ & $139 \pm 0.52^{\mathrm{b}}$ \\
Weight of First Egg (WFE) (g) & $43.28 \pm 0.05^{\mathrm{a}}$ & $38.40 \pm 0.04^{\mathrm{c}}$ & $40.50 \pm 0.04^{\mathrm{b}}$ \\
\hline
\end{tabular}

$a, b, c=$ Means in the same row with different superscript differ significantly $(P>0.05)$. SEM $=$ standard error of the mean.

egg widths observed in this study were slightly higher than values reported by Amaefule et al. (2007) who recorded values ranging from 4.23 to $4.31 \mathrm{~cm}$ in layers fed raw or processed pigeon pea seed meal during laying stage. The average egg widths observed in this study were also higher than the value $3.3 \mathrm{~cm}$ reported by Oladunjoye et al. (2010) who substituted maize with 50 to $80 \%$ sun-dried cassava peel meal and treated cassava peel meal respectively. The mean values of egg weight observed in this study were comparable to the values reported by Mosobolaja et al. (2010) and Abeke et al. (2007) who fed processed pigeon pea and graded levels of Lalabpurpureus bean diets to layers of comparable age bracket. However, mean egg weights obtained in this study were higher than those obtained by Oladunjoye et al. (2010) who fed 50 to $80 \%$ graded levels of sun-dried and lye-treated cassava peel meal to pullets from 32 weeks of age. Salami and Odunsi (2003) reported higher egg weights $(60.20$ to $66.70 \mathrm{~g}$ ) in older birds (66 to 72 weeks) fed retted cassava peel meal based diets.

Significant differences $(P<0.05)$ were also observed in age at first egg (AFE) among pullets on the three dietary groups. Pullets on the control diet had the lowest AFE, $138 \pm 0.80$ days, which suggests that inclusion of cassava peel meal in the diet of pullets may have prolonged AFE. Abeke et al. (2007) obtained higher AFE values in layers fed grower diets containing graded levels of Lablab purpureus beans meal. Akanni et al. (2008) reported AFE values of 190.93, 138.24, 160.76, 188.73 and 177.00 days for Nera black, White Leghorn, Giriraja, local and BAlpha breeds of chicken respectively. Significant differences $(P<0.05)$ were also observed in weight at first egg (WFE) of pullets on the three dietary groups. Pullets on the control diet also recorded highest WFE, $43.28 \pm 0.05 \mathrm{~g}$, although WFE did not follow any defined pattern.

There were also significant differences in hatchability and infertility of eggs of pullets on the three dietary groups $(P<0.05)$. Hatchability of eggs from the three dietary groups did not follow any defined pattern as revealed in this study. Factors that could be responsible for the low hatchability values in this study were the status of breeding stock, environmental temperature and inadequate turning of eggs. However, the result revealed that as the inclusion level of cassava peel meal in the diets increased, infertility of eggs decreased. Hatchability is a function of fertility except when there is occurrence of major genes that reduce embryonic livability (Akanni et al., 2008). The fertility rate observed in this study is low compared to the ideal, which is supposed to be between 90 to $95 \%$. Akanni et al. (2008) obtained percentage fertility rate of 73.85 to $77.00 \%$ for black Nera, local and B-Alpha improved indigenous crossbred chickens. The hatchability observed in this study, which is based on number of fertile eggs, was too low compared to established levels of 85 to $87 \%$ (Jadhav and Siddiqui, 2007). Bovans (2004) obtained hatchability value of $80 \%$ for Bovan breed of pullets. Akanni et al. (2008) recorded hatchability values of 86,73 and $75 \%$ for local, black Nera and B-Alpha improved indigenous crossbred chickens respectively. The low hatchability observed in this study could be because hatching was done in the dry season when the environmental temperature was too high for keeping of eggs. The humidity, levels of oxygen and carbon (iv) oxide may not have been adequate because of environmental temperature.

\section{Conclusion and recommendation}

Cassava peel meal is a good alternative source of energy to chickens and can be included up to a level of $20 \%$ in the diets of pullets without any deleterious effect on egg length, egg width, egg shape index, egg weight, shell weight, shell thickness and albumen height. It is therefore recommended that cassava peel meal could be used to replace maize up to $20 \%$ in the diets of layer chickens.

\section{CONFLICT OF INTEREST}

The authors declare that they have no conflict of interest. 


\section{REFERENCES}

Abeke, F. O., Ogundipe, S., Sekoni, A. A., Dafwang, I. I., Adeyinka, I. A., Oni, O. O., \& Abeke, A. (2007). Effect of duration of cooking of Lablab purpureus beans on the performance organ weight and haematologicalparmeters of Shikka brown pullet chicks. J. Biol. Sci., 7(3), 562-565.

Ahmadi, F., \& Rahimi, F. (2011) Factors affecting quality and quantity of egg production in layers: a review. World Appl. Sci. J., 12(3), 372-384.

Akanni, K. T., Peters, S. O., Adebambo, O. A., Adebambo, F. A., \& Omoare, A. M. (2008). Comparative laying performance in pure and crossbred chickens in Southwestern Nigeria. Proceedings of $23^{\text {rd }}$ Annual Conference of Nigerian Society for Animal Production held at the University of Calabar. Pp. 10-13

Amaefule, K. U., Oke, U. K., \& Obioha, F. C. (2007). Pigeon pea (Cajanuscajan) seed meal in layer diets 2. Laying performance of pullets fed raw or processed pigeon pea seed meal diets during grower and layer stages of life. Int. J. Poult. Sci., 6(6), 445-451.

Anaeto, M., Sawyerr, A. F., Alli, T. R., Tayo, G. O., Adeyeye, J. A., \& Olarinmoye, A. O. (2013). Cassava Leaf Silage and Cassava Peel as Dry Season Feed for West African Dwarf Sheep. Global J. Sci. Frontier.Res. Agric. Vet. Sci., 13(2), 1-4.

Bovans, N. (2004). Hendrix Poultry Breeders. www.hendrixisa.com/en.

Esonu, B. O., Azubuike J. C., \& Ukwu, H. O. (2004). Evaluation of Microdesmispuberula leaf meal as feed ingredient in laying hen dies. Int. J. Poult. Sci., 3(2), 96-99.

Irekhore, O. T, Bamgbose, A. M., \& Olubadewa G. A. (2006). Utilization of cassava peel meal as energy source for growing pigs. J. Anim. Vet. Adv., 5(10), 849-851.

Jadhav, N. V., \& Siddiqui, M. F. (2007). Poultry production systems. Handbook of poultry production and management. Jaypee Brothers Medical Publishers $(P)$ Ltd. $2^{\text {nd }}$ Edition, Pp. 44-112.
Mosobolaja, M. A., Tewe, O. O., \& Adedoyin, A. A. (2010). Economic evaluation of performance of layers fedcassava root products as replacement for maize. Proceeding of the $35^{\text {th }}$ Conference of Nigeria Society for Animal Production, 1417 March, 2010, University of Ibadan, Nigeria, Pp. 394-396.

Obiakonu, H. O., \& Udedibie, A. B. I. (2007). Antinutritional factors and processing methods of cassava peels. Proceeding of the $32^{\text {nd }}$ Conference of Nigeria Society for Animal Production, Calabar, March 18-21, 2007, Pp. 307310.

Oladunjoye. I. O., Ojebiyi, O., \& Amao, O. A. (2010). Effect of feeding processed cassava peel meal (Manihot exculenta crantz) peel meal based diet on the performance characteristics, egg quality and blood profile of laying chicken. Agricultural Tropica Et Subtropica, 43(2), 119-126.

Olowofeso, O., \& Omisami, O. O. (2008). Utilization of cassava peels treated with yeast culture by egg laying hens. Proceeding of the $32^{\text {nd }}$ Conference of Nigeria Society for Animal Production, Pp. 492-495.

Oladunjoye, I. O., Ojebiyi, O., \& Amao, O. A. (2010). Effect of feeding processed cassava peel meal based diet on the performance characteristics, egg quality and blood profile of laying chicken. Agric. Tropica Et Subtropica, 43(2), 119-126.

Salami, R. I., \& Odunsi, A. A. (2003) Evaluation of Processed Cassava Peel Meals as Substitutes for Maize in the Diets of Layers. International Journal of Poultry Science, 2(2), 112116.

SPSS (IBM) Statistics for windows, version 20.0. released 2011, Armonk, NY:IBM Corp. 